\title{
Analysis of the Presence of Clostridium perfringens in Feed and Raw Material Used in Poultry Production
}

\author{
Eliana Neire Castiglioni Tessari, Ana Lúcia S. Paschoal Cardoso, \\ Ana Maria Iba Kanashiro, Greice F. Zanatta Stoppa, Renato Luis Luciano, \\ Antonio Guilherme Machado de Castro \\ Instituto Biológico-Centro Avançado de Pesquisa Tecnológica do Agronegócio Avícola, Descalvado, Brazil \\ Email: etessari@biologico.sp.gov.br
}

Received 18 December 2013; revised 18 January 2014; accepted 25 January 2014

Copyright (C) 2014 by authors and Scientific Research Publishing Inc.

This work is licensed under the Creative Commons Attribution International License (CC BY).

http://creativecommons.org/licenses/by/4.0/

c) (i) Open Access

\begin{abstract}
Microbiological control of feeds used in industrial poultry production has been increasingly important due to the demands of the market for food safety, as well as the need to ensure better quality of the digestive system of the birds. Microbiological analysis carried out in raw material used in feed production, especially feather, meat, and organ meal, has shown contamination by Clostridium perfringens. In order to study the presence of Clostridium perfringens, a total of 354 samples of feed and raw material were analyzed from January 2011 to July 2013. Samples came from four companies located in the state of São Paulo, with a total of 166 samples of meat meal, 24 samples of feather meal, 43 samples of organ meal, and 121 samples of feed. The following results were obtained: 88 (53\%), 15 (62.5\%), $16(37.21 \%)$, and 23 (19\%) samples were positive for Clostridium perfringens in each group of samples, respectively, with counts ranging from $2.0 \times 10^{2}$ to $7.0 \times 10^{3} \mathrm{CFU} / \mathrm{g}$.
\end{abstract}

\section{Keywords}

Necrotic Enteritis; Clostridium perfringens; Feed

\section{Introduction}

Control of microbiological contamination in feed and raw materials begins with good sampling programs and laboratory analyses in order to identify sources of contamination and to determine control strategies.

Among the different vehicles of pathogens in the poultry production chain, the contamination of feed and raw material for feed production should be highlighted. These are common vehicles of different pathogenic bacteria that may cause clinical and/or subclinical effects in birds, leading to inadequate performance and, consequently, 
to economic losses. Clostridium perfringens is among the bacteria involved in this contamination. The agent causes necrotic enteritis in birds, and may be found in the intestinal content and feces of the birds, as well as in dirt, contaminated food, bedding material, and other sources [1].

Microbiological analyses carried out in raw material used in feed production, mainly feather, meat, and organ meal have shown different levels of contamination by C. perfringens, depending on the quality of the raw material and on the hygienic procedures used during processing [2]. These sources, when contaminated, may be vehicles of important pathogens for the flocks [3] [4], leading to decreased feed efficiency and health problems, which end up in the development of diseases and considerable economic losses to this production system.

In grains, soybean meal and meals of animal origin, different microorganisms may be found. Some of them are resistant to low moisture conditions and may survive for a long periods. Contamination levels reported in the literature range from $5 \times 10^{3}$ to $1.6 \times 10^{8} \mathrm{CFU} / \mathrm{g}$ [5] [6]. Contamination by bacteria is frequent, with Salmonella spp. and Clostridium sp. among them. The main source of contamination is the raw material, such as grains and oily seeds, which becomes contaminated by the dust of the soil where the plants are grown, and is carried by the wind, rain, and by mechanical removal of the plants in the field [1].

In several outbreaks of necrotic enteritis, feed and bedding material are among the main sources of infection. The disease is observed as acute enterotoxaemia, in clinical or subclinical form [7], and it is caused by C. perfringens A and C. It is characterized by ulcerative lesions and confluent necrosis of the mucosa of the small intestines, leading to debility which develops quickly. It mainly affects young animals, two to five weeks of age, and the onset is sudden, generally associated with immunosuppression. Death ensues quickly and with high prevalence [8]. Broilers, commercial laying hens, turkeys, quails, ostriches and wild birds are susceptible, with large economic losses and problems related to animal welfare, due to the increasing percentage of mortality in the clinical cases [9].

The need of controlling the presence of microrganisms in bird feed is undeniable, mainly due to the recent changes in safety regulations for foods associated with the increased demands of the consumers and related to sanitary issues. The presence of these microorganisms in bird feed may also be considered in relation to the biosafety of the lots and the performance of the animals [10].

Therefore, to maintain a microbiological analysis program in raw materials used in feed production, such as meals of animal origin, it is necessary to monitor the contamination profile of these ingredients, and to determine minimum standards of quality. The objective of the present study was to analyze the presence of Clostridium perfringens in feed and raw material used in commercial poultry operations.

\section{Material and Methods}

A total of 354 samples were analyzed, with 166 of meat meal, 24 of feather meal, 43 of organ meal, and 121 of feed, which were collected in four companies located in the state of Sao Paulo, from January 2011 to July 2013. The methodology used in this study was performed as described by Barnes [11] and FDA [12], $1 \mathrm{~mL}$ of each dilution was placed in Petri dishes. They were then added of $15 \mathrm{~mL}$ of molten TSC (Triptose Sulfite Cycloserine Agar $^{\circledR}$, BD DIFCO, Le Pont de Claix, France) or SFP (Shahadi Ferguson Perfringens Agar ${ }^{\circledR}$, BD DIFCO, Le Pont de Claix, France). Agar in the plates was homogenized, and plates were stored in anaerobic jars, without inversion of the plates, at $36^{\circ} \mathrm{C} \pm 1{ }^{\circ} \mathrm{C}$ for 24 hours. After that, colonies were counted in plates that had from 30 to 300 colonies.

Clostridium sp. form dark colonies due to the reduction of sulfite to sulfide, which reacts with ammonium and iron citrate, forming a black precipitate. From these plates five black colonies were chosen and added to thioglycollate broth for 24 - $48 \mathrm{~h}$ for gas production. After gas was produced, the following biochemical tests were carried out: fermentation (based on the fermentation of milk containing iron, producing large amounts of gas, characteristic of Clostridium perfringens); liquefaction of gelatin and lecithinase test. When these three biochemical tests were positive for the colonies tested, samples were considered positive for the presence of $C$. perfringens.

\section{Results and Discussion}

The following results were obtained in the isolation of C. perfringens: 88 positive samples in meat meal, corresponding to $53 \%$ of them; 15 samples positive in feather meal (62.5\%); in organ meal, 16 samples were positive (37.21\%), and in feed samples, 23 were positive, corresponding to $19 \%$ of them. Counts ranged from $2.0 \times$ $10^{2}$ to $7.0 \times 10^{3} \mathrm{CFU} / \mathrm{g}$. The results are showed in Table 1 . 
Table 1. Analysis of Clostridium perfringens for meat meal, feather meal, organ meal and feed and limits acceptable of contamination.

\begin{tabular}{ccccc}
\hline Sample & Positive/total $^{\mathrm{a}}$ & $\%$ & Negative/total $^{\mathrm{b}}$ & $\%$ \\
\hline Meat meal & $88 / 166$ & 53 & $78 / 166$ & $9 / 24$ \\
Feather meal & $15 / 24$ & 62.5 & $27 / 43$ & 37.5 \\
Organ meal & $16 / 43$ & 37.2 & $98 / 121$ & 62.8 \\
Feed & $23 / 121$ & 19 & & 81 \\
& Regulament [18] & & & \\
Limit acceptable & Absence & & & \\
\hline
\end{tabular}

${ }^{\mathrm{a}}$ Results are expressed as number of positive samples/total number of samples tested. ${ }^{\mathrm{b}}$ Results are expressed as number of negative samples/total number of samples tested.

Studies carried out all over the world prove the presence of spores in products used in animal feed production, in amounts that vary according to the raw material under analysis. Wojdat et al. [13] detected C. perfringens in $38 \%$ of the samples of ingredients used in the production of broiler feed, with the greatest indices observed in meals of animal origin, once these products presented high concentrations of protein.

In the European Union, McDevitt et al. [14] observed that the incidence of the clinical and subclinical forms of the disease increased, ranging from $1 \%$ to $40 \%$, after the banning of Gram-positive additives from poultry feeds.

In a study conducted in Spain, Prió et al. [15] observed that the level of contamination by Clostridium sp. found in different ingredients for animal nutrition is widely variable.

Richardson [16] analyzed the presence of different microorganisms in feed from different feed plants, and observed that the level of contamination of the feed collected in the silo of the poultry facility was always greater than the level of contamination of the feeds collected in the plants. The study pointed out that the strategies to control microbiological contamination adopted by the feed plants do not ensure the absence or low counts of bacteria and fungi until the moment of feed is placed in the feeders in the poultry facility. Therefore, the use of strategies to control the levels of contamination of the raw materials until the final destination of the feed (the feeder) is warranted.

In a survey of 2049 samples, Richardson [17] observed that C. perfringens may also be isolated in different ingredients used in bird and pig feed. The levels of contamination of these samples ranged from 10 to 2000 $\mathrm{CFU} / \mathrm{g}$.

Schocken-Iturrino and Ishi [8] analyzed C. perfringens contamination in samples of meals of animal origin, such as organ, feather and meat, used in poultry feed production, and found counts of up to $3.2 \times 10^{4} \mathrm{CFU} / \mathrm{g}$.

In a survey conducted in three different cities of the state of Sao Paulo, Schocken-Iturrino et al. [4] observed that, among 90 samples of broiler feed analyzed, $42 \%$ were contaminated by $C$. perfringens, and mean counts were $3.69 \times 10^{2} \mathrm{CFU} / \mathrm{g}$. The high counts found in this survey were associated in Good Manufacturing Practices failures, mainly the lack of hygiene in the production and little care in the storage of the feeds.

\section{Conclusion}

Microbiological control of feed ingredients and poultry feed has been considered increasingly relevant due to the demands of the market for food safety all over the production chain, besides the perception of greater challenges in field condition that may lead to economic losses in bird lots.

\section{References}

[1] Longo, F.A., Silva, I.F. and Lanzarin, M.A. (2010) The Importance of Microbiological Control in Poultry Rations. XI Poultry Symposium of South Brazil and Poultry Fair II South Brazil, Chapecó, 6-8 April 2010.

[2] Berchieri Júnior, A. and Macari, M. (2010) Doença das aves. 1st Edition. Facta, Campinas, 490 p.

[3] Jaenisch, F.R.F. (2003) Sistemas de Produção de Frangos de Corte: Cuidados com a Ração e a Água. Embrapa Suinos e Aves. http://sistemasdeproducao.cnptia.embrapa.br/FontesHTML/Ave/ Producao de Frango de Corte/Cuidados-racao.html

[4] Schocken-Iturrini, R.P., Vittori, J., Beraldo-Massoli, M.C., Delphino, T.P.C. and Damasceno, P.R. (2010) Clostridium 
Perfringens em Rações e Águas Fornecidas a Frangos de corte em Granjas Avícolas do Interior Paulista. Revista Ciência Rural, 40, 197-199. http://dx.doi.org/10.1590/S0103-84782010000100033

[5] Multon, J.L. (1988) Spoilage Mechanisms of Grains and Seeds in the Post-Harvest Ecosystem, There Sultinglosses and Strategies for the Defense of Stocks. In: Multon, J.L., Ed., Preservation and Storage of Grains, Seeds, and Their By-Products, Lavoisier Publishing, New York, 3-5.

[6] Richards-Molard, D. (1988) General Characteristics of the Microflora of Grains and Seeds and the Principal Resulting Spoilages. In: Multon, J.L., Ed., Preservation and Storage of Grains, Seeds, and Their By-Products, Lavoisier Publishing, New York, 226-243.

[7] Van Immerseel, F. (2004) Clostridium Perfringens in Poultry: An Emerging Threat for Animal and Public Health. Avian Pathology, 33, 537-549. http://dx.doi.org/10.1080/03079450400013162

[8] Schocken-Iturrino, R.P. and Ishi, M. (2000) Clostridioses em Aves. In: Berchieri Jr., A. And Macari, M., Eds., Doenças das Aves. Facta, Campinas, 242-243.

[9] Lovland, A. and Kaldhusdal, M. (2001) Severely Impaired Production Performance in Broiler Flocks with High Incidence of Clostridium Perfringens-Associated Hepatitis. Avian Pathology, 30, 73-81. http://dx.doi.org/10.1080/03079450020023230

[10] Richardson, K.E. and Longo, F.A. (2008) A Importância do Controle Microbiológico na Cadeia de Produção de Rações para Aves. In: Anais do V Simpósio sobre Manejo e Nutrição de Aves e Suínos, CBNA, Cascavel, 149-160.

[11] Barnes, H.J. (2003) Isolamento de Clostridium Perfringens. In: Diseases of Poultry, Iowa State University Press, Ames, 797-859.

[12] FDA (2001) Contagem de Clostridium Perfringens Bacteriological Analytical Manual. Chapter 16, Food and Drug Administration, Clostridium Perfringens. http://www.fda.gov/food/foodscienceresearch/laboratorymethods/ucm070878.htm Acessed in 20/11/2013

[13] Wojdat, E., Kwiatek, K. and Kozak, M. (2006) Occurrence and Characterization of Some Clostridium Species Isolated from Animal Feeding Stuffs Bull. Veterinary Institute Pulawy, 50, 63-67.

[14] McDevitt, R.M., Brooker, J.D., Acamovic, T. and Sparks, N.H.C. (2006) Necroticenteritis; a Continuing Challenge for the Poultry. World's Poultry Science Journal, 62, 221-247.

[15] Prió, P., Gasol, R., Soriano, R.C. and Perez-Rigau, A. (2001) Effect of Raw Material Microbial Contamination over Microbiological Profile of Ground and Pelleted Feeds. In: Brufan Journal, From Feed to Food, Ciheam, Zaragoza, 197199.

[16] Richardson, K.E. (2007) A Importância do Controle Microbiológico em Rações de Aves. In: Anais do Congresso Internacional sobre Nutrição Animal e Alimentos Seguros, CBNA, Campinas, 43-54.

[17] Richardson, K.E. (2008) Reemergence of Clostridia Perfringes: Is It Feed Related. Proceedings of 20th Central American Poultry Congress, Managua, Nicaragua, Septtember 2008, 190 p.

[18] (2002) Regulation (EC), $n^{\circ} 1774 / 2002$ of the European Parliament and of the Council of 3 October 2002 Laying Down Health Rules Concerning Animal By-Products not Intended for Human Consumption Official Journal of the European Communities, $\mathrm{n}^{\circ} \mathrm{L} 273,0001-0095$. 